http://cakrawalajournal.org/index.php/cakrawala Volume 15 Nomor 2 Desember 2021

JURกคL UTBВคกG KEBIJดKคก

Cakrawala: Jurnal Litbang Kebijakan has been accredited as a scientific journal by the Ministry of Research-Technology and Higher Education

Republic of Indonesia: No. 28/E/KPT/2019 [SINTA-5]

\title{
Kemandirian Ekonomi Masyarakat Desa Berbasis Pemanfaatan Aset Produktif di Kabupetan Mojokerto
}

Village Community Economic Independence Based on the Use of Productive Assets in Mojokerto Regency

\author{
${ }^{\square}$ Aulya Putri Maghfiroh, Ana Toni Roby Candra Yudha, Alda Pradessari, \\ Setyani Agung Dwi Astuti \\ Universitas Islam Negeri Sunan Ampel Surabaya, Indonesia \\ DOI: $10.32781 /$ cakrawala.v15i2.360
}

\section{ARTICLE INFO \\ PNPM, \\ Aset Produktif, \\ Kemandirian Masyarakat.}

Article History:

Received : 13 Nov 2020

Accepted : 06 Nov 2021

Publish : 22 Des 2021

\begin{abstract}
Abstrak:
Penelitian ini bertujuan untuk mengetahui keberhasilan dorongan aset produktif bagi kemandirian masyarakat melalui upaya pemberdayaan masyarakat oleh PNPM. Metode penelitian ini menggunakan pendekatan kualitatif dengan strategi etnografi yang dilaksanakan di Kecamatan Gondang, Kabupaten Mojokerto dalam kurun waktu bulan Agustus sampai September 2020. Data yang digunakan yaitu data primer yang diperoleh melalui wawancara mendalam. Peneliti juga menggunakan data sekunder yang berupa arsip dan dokumen.Hasil dari penelitian ini menunjukkan bahwa upaya peningkatan kemandirian masyarakat melalui program pemberdayaan masyarakat PNPM cenderung terfokus pada peningkatan aset produktif dan belum sepenuhnya difokuskan pada keberhasilan kemandirian masyarakat melalui kegiatan pemberdayaan masyarakat. Adapun saran yang beresesuaian dengan hasil penelitian yaitu agar UPK Kecamatan Gondang menyeleksi masyarakat yang melakukan kredit pada program UEP untuk memastikan bahwa penggunaannya benar-benar diperuntukkan bagi pengembangan usaha serta melakukan mentoring secara berkala pada kelompok binaan sebagai bentuk evaluasi pemberdayaan.
\end{abstract}

\section{Abstract:}

This study aims at determining the success of encouraging productive assets for community independence through community empowerment efforts by PNPM. This research method uses a qualitative approach with an ethnographic strategy carried out in Gondang District, Mojokerto Regency, from August to September 2020. The data that used are primary data obtained through in-depth interviews. The researcher also uses secondary data in the form of archives and documents. This study indicates that the efforts to increase community independence through the PNPM community empowerment program tend to focus on increasing productive assets and have not fully focused on community independence through community empowerment activities. Some suggestions are following the research result, namely that the Gondang District UPK should select the community who credit the UEP program to ensure that its use is intended for business development and periodically providing mentoring to the target groups as a form of empowerment evaluation.

\footnotetext{
${ }^{\top}$ Corresponding author :

Address : Jl. Ahmad Yani No.117, Jemur Wonosari, Kec. Wonocolo, Kota SBY

Email : aulyaputrimaghfiroh@gmail
}

Hal. 139-152

p-ISSN 1978-0354 | e-ISSN 2622-013X 
PENDAHULUAN

Indonesia merupakan negara dengan penduduk yang mayoritas bekerja pada sektor informal seperti UKM, pedagang pasar, petani dan warung pracangan. Adanya sektor informal memiliki pengaruh terhadap perekonomian nasional. Di Indonesia, dari seluruh sektor yang ada, sektor informal mengisi dua pertiga perekonomian nasional. (Paralaungan, 2016). Banyaknya penduduk Indonesia yang bekerja pada sektor informal, bahkan lebih dari 50\% menunjukkan bahwa keberadaan sektor informal benar diakui sehingga segala bentuk kendala didalamnya menjadi tanggungjawab pemerintah melalui kebijakan ekonomi. Disisi lain, tingginya penduduk yang bekerja pada sektor informal memberikan kontribusi terhadap pertumbuhan ekonomi di Indonesia. Pertumbuhan ekonomi menjadi komponen terpenting sebagai tolak ukur kesejahteraan dan kemakmuran suatu negara (A. T. R. C. Yudha \& Prayitno, A., Rahmaning, D., \& Maulana, 2018).

Pulau Jawa yang jumlah penduduknya setara dengan hampir setengah penduduk di Indonesia menjadi wilayah dengan sektor informal terbesar di Indonesia. Hal tersebut sebanding dengan sebaran jumlah penduduk di Pulau Jawa. Provinsi Jawa Timur merupakan salah satu provinsi di Pulau Jawa yang berkontribusi pada sektor informal terbesar di Indonesia (BPS, 2019). Hal tersebut membuktikan bahwa Jawa Timur merupakan salah satu provinsi yang memiliki fundamental ekonomi berbasis industri mikro dan pemanfaatan aset produktif yang dibuktikan dengan adanya perkembangan permodalan nasional madani (Winarsih et al., 2019), koperasi wanita dan berbagai bantuan berupa aset produktif yang disalurkan oleh pemerintah kepada masyarakat (Reginald \& Mawardi, 2015).

Dalam penyaluran aset produktif oleh pemerintah (Mardiyah \& Ryandono, 2016), Kabupaten Mojokerto turut andil dalam menyukseskan program ekonomi mandiri melalui Program Nasional Pemberdayaan Masyarakat (PNPM). Mojokerto merupakan salah satu kabupaten yang berkesampatan memperoleh bantuan dana bergulir PNPM Mandiri Pedesaan. yang dicanangkan pada tahun 2006. PNPM merupakan keberlanjutan dari program

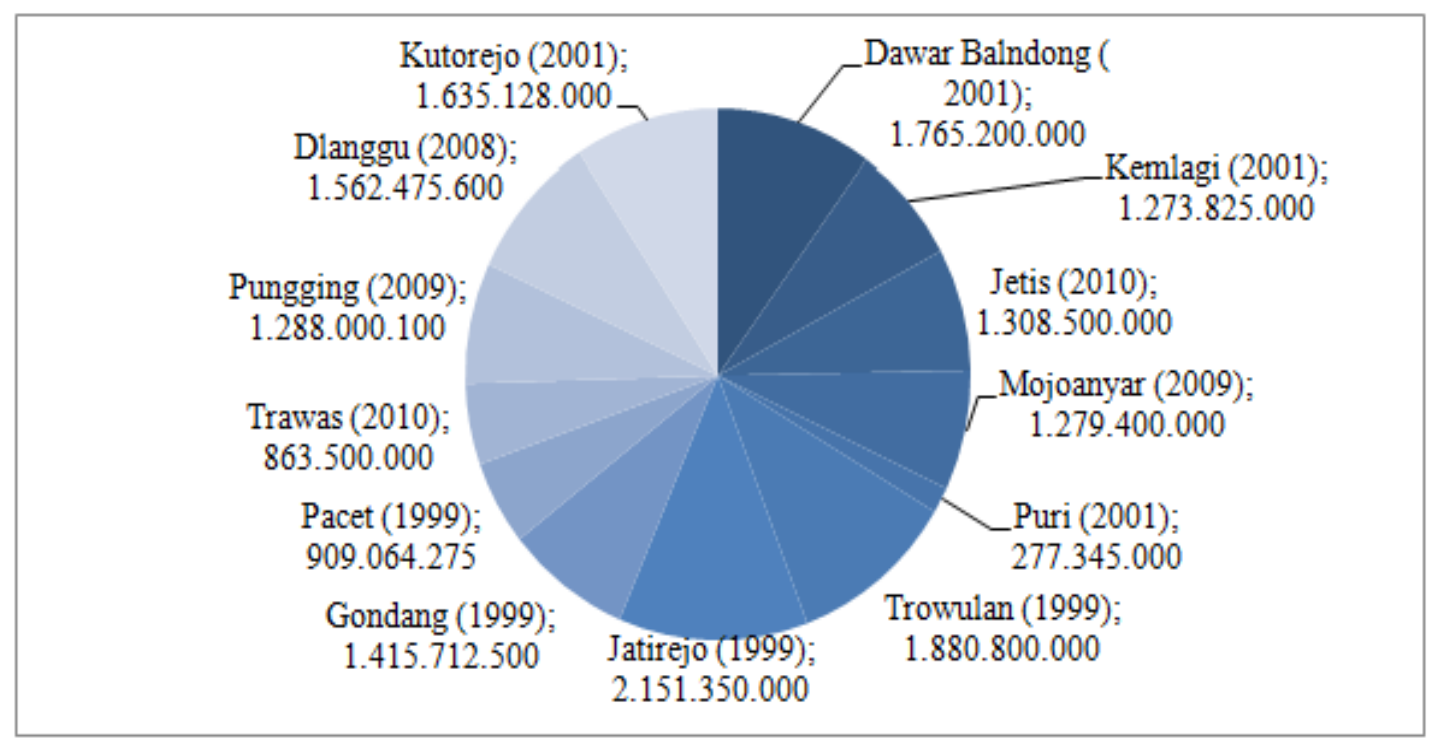

Sumber: DPMD Kab. Mojokerto Diolah, 2020

Gambar 1

Tahun dan Modal Awal Perguliran Dana 
sebelumnya yaitu Program Pengembangan Kecamatan (PPK) yang dibentuk pada tahun 1998 untuk menanggulangi permasalahan kemiskinan (Muslim, 2017). Dari 18 kecamatan di kabupaten Mojokerto, hanya 13 kecamatan yang mendapatkan perguliran dana (A. T. R. C. Yudha \& Muizz, 2020). Hal, tersebut dilihat dari perkembangan pertumbuhan ekonomi setiap kecamatan. Kecamatan yang berhak memperoleh perguliran dana PNPM yaitu kecamatan yang tingkat kemiskinannya tinggi, angka pengangguran tinggi dan infrastruktur yang kurang memadai dan jauh dari fasilitas publik. Total perguliran dana PNPM Mandiri Pedesaan se Kabupaten Mojokerto senilai Rp 17.610.300.475 yang kemudian digulirkan ke 13 kecamatan di Kabupaten Mojokerto.

Berdasarkan data dan informasi yang tertera pada gambar 1 dapat diamati bahwa, perguliran dana aset produktif di setiap kecamatan tidak dilakukan secara serentak ditahun yang sama dan dengan jumlah dana yang berbeda-beda. Kecamatan Kutorejo, Pacet, Gondang, Jatirejo, Trowulan, Puri, Kemlagi dan Dawar Blandong, menggulirkan dananya dilaksanakan pada saat Program Pengentasan Kemiskinan (PPK) yaitu antara tahun 1999 hingga 2006. Sedangkan 4 kecamatan lainnya yaitu Kecamatan Dlanggu, Pungging, Jetis dan Trawas, dilaksanakan perguliran dana setelah terbentuknya PNPM Mandiri Pedesaan.

Jumlah besaran aset produktif yang digulirkan dan tahun perguliran dana yang berbeda-beda dilatarbelakangi oleh kondisi masing-masing kecamatan. Adapun faktor-faktor yang dimaksud tersebut diantaranya adalah tingkat kemiskinan, tingkat pengangguran, dan infrastruktur yang kurang memadai dan jauh dari fasilitas publik. Tujuan perguliran dana tersebut sebagai stimulan agar dapat dimanfaatkan dan dikelola secara produktif dan berkelanjutan. Berikut perkembangan aset produktif masing-masing kecamatan.

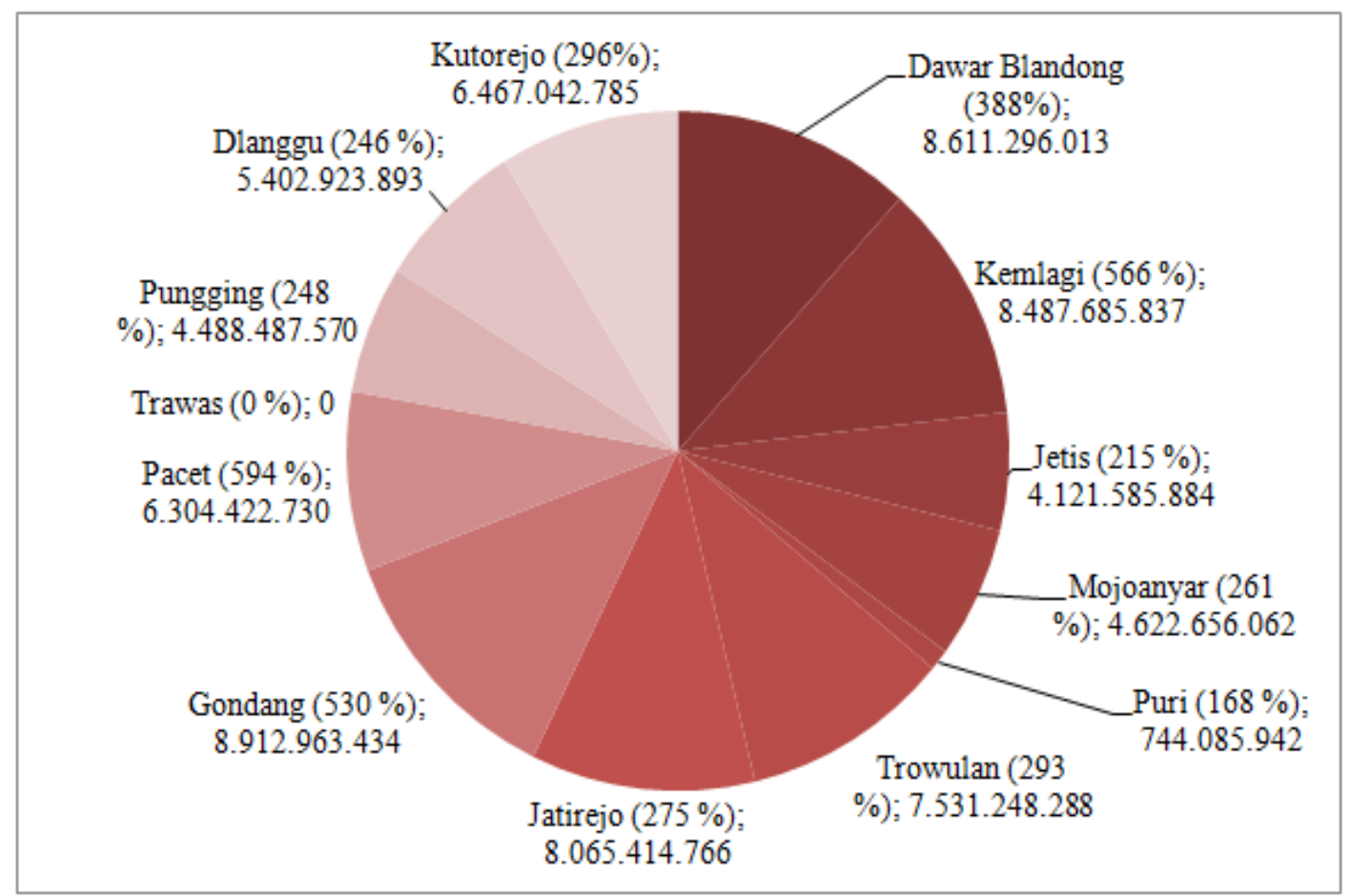

Sumber: DPMD Kab. Mojokerto Diolah, 2020

Gambar 2

Persentase dan Total Aset Produktif 
Dilihat pada gambar 2, total perkembangan aset produktif masing-masing kecamatan jika disesuaikan masing-masing tahun perguliran dana pada gambar 1 diperoleh hasil bahwa Kecamatan Pacet merupakan kecamatan dengan kenaikan aset tertinggi dengan persentase 594\%. Namun, aset diatas belum dikurangi tunggakan selama tahun berjalan, sehingga untuk mengetahui produktifitas perguliran dana, aset harus dikurangi tunggakan. Data aset yang telah dikurangi tunggakan pun ditampilkan pada diagram dibawah ini.

Dari gambar 3 diatas, dapat dilihat bahwa Kecamatan Gondang merupakan kecamatan dengan aset produktif tersebesar senilai Rp 8.565.556.558 setelah dikurangi tunggakan. Selain itu, jika dilihat dari data dilapangan, Kecamatan Gondang menjadi kecamatan dengan aset terbesar karena satu-satunya kecamatan yang memiliki aset berupa bangunan senilai Rp 1.100.000.000 yang dibeli dari hasil pengelolaan aset produktif untuk keperlua operasional. Sehingga jika ditotal aset produktif yang saat ini berjalan yaitu Rp 8.912.963.434 dan aset tetap berupa bangunan yaitu $\mathrm{Rp}$ 1.100.000.000, maka Kecamatan Gondang menjadi kecamatan dengan aset terbesar se-Kabupaten Mojokerto senilai Rp 10.012.963.434.

Mengacu pada hasil diatas yang menunjukkan bahwa Kecamatan Gondang dapat mengelola aset produktif berupa dana bergulir dengan baik (Zustika \& Yudha, 2020), dibuktikan dengan besarnya aset yang dimiliki serta rendahnya tunggakan. Hal tersebut merupakan capaian tersendiri bagi Kecamatan Gondang sebagai salah satu kecamatan yang pertama kali menerima dana bergulir serta dapat mengelola dengan baik sehingga dapat menjadi acuan bagi kecamatan lain di Kabupaten Mojokerto.

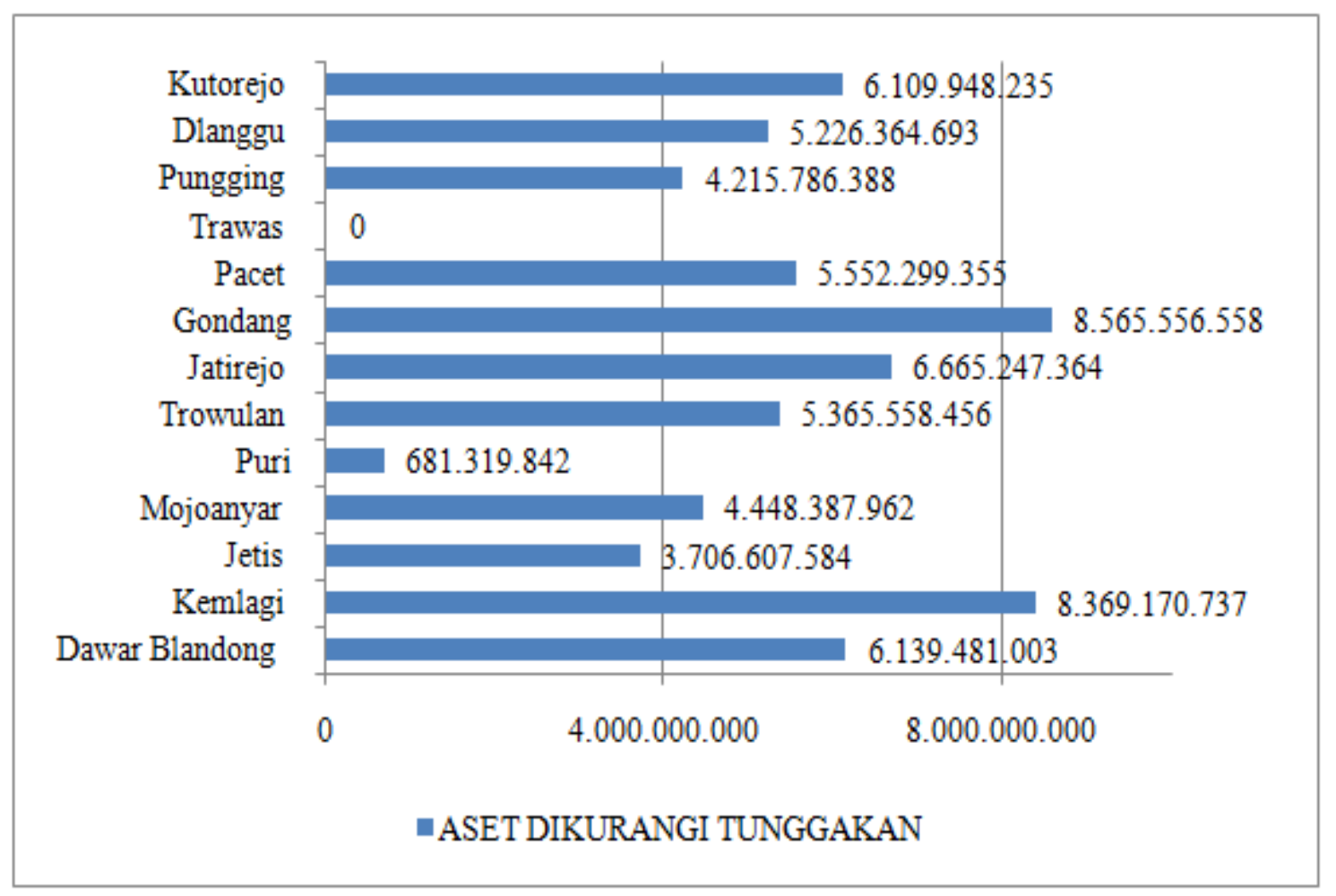

Sumber: DPMD Kab. Mojokerto, 2020

\section{Gambar 3}


Dari latar belakang yang telah diuraikan diatas, maka yang menjadi rumusan masalah pada penelitian ini yaitu, pertama, bagaimana tim UPK mampu mengelola dan menarik minat masyarakat Kecamatan Gondang untuk turut aktif dalam mengelola dana bergulir PNPM sehingga aset produktifnya dapat berkembang dan lestari? kedua, apakah dana bergulir Usaha Ekonomi Produktif dapat sepenuhnya dimanfaatkan dengan tepat oleh masyarakat sasaran ?.

Adapun tujuan penelitian ini adalah untuk mengetahui keberhasilan dorongan aset produktif bagi kemandirian masyarakat melalui upaya pemberdayaan masyarakat oleh PNPM desa setempat. Tujuan utama tersebut dapat dicapai dengan, Pertama, upaya tim UPK dalam mengelola dan mengedukasi masyarakat, serta menarik minat masyarakat untuk turut aktif dalam mengelola, dan Kedua adalah, memastikan kemanfaatan dana bergulir yang disalurkan pada masyarakat desa setempat di Kecamatan Gondang.

\section{TINJAUAN PUSTAKA}

Adapun ulasan teoritis yang mendukung ulasan pembahasan sekaligus elaborasi materi, diperlukan beberaba teori dan subteori yang relevan dengan konsep penelitian yang diangkat. Berikut ulasan teori yang dimaksud.

\section{Kemandirian Masyarakat}

Peraturan Menteri Dalam Negeri RI No. 7 Tahun 2007 Pasal 8 tentang Kader Pemberdayaan Masyarakat menyatakan bahwa pemberdayaan masyarakat merupakan strategi dalam pembangunan masyarakat yang bertujuan untuk membentuk kemampuan dan kemandirian dalam kehidupan bermasyarakat, berbangsa dan bernegara (Pusposari et al., 2015). Jadi, inti dari pemberdayaan masyarakat yaitu cara yang digunakan untuk mewujudkan masyarakat yang mandiri dan tidak berpangku tangan pada pemerintah (A. Yudha et al., 2021), melainkan dibentuk untuk dapat mengelola segala bentuk bantuan yang diberikan oleh pemerintah sebagai stimulan (Ab Rahman et al., 2019).

\section{Program Nasional Pemberdayaan Masyarakat (PNPM) \\ Program Nasional Pemberdayaan} Masyarakat (PNPM) merupakan salah satu program yang dibentuk oleh pemerintah sebagai upaya untuk meingkatkan kesejahteraan masyarakat pedesaan serta meningkatkan kinerja pemerintah daerah (Dewi et al., 2021). Kebijkan pada Program Nasional Pemberdayaan Masyarakat (PNPM) dibentuk dengan tujuan untuk memepercepat proses penanggulangan kemiskinan secara terpadu dan bekelanjutan (Novalianis, 2011). PNPM mendanai berbagai kegiatan pembangunan atau perbaikan sarana dan prasaran, pelatihan pengembangan ketrampilan masyarakat (Syamsuar \& Reflianto, 2018), peningkatan kapasitas kelompok usaha serta pemodalan simpan pinjam untuk kelompo Simpan Pinjam Perempuan (SPP) dan Usaha Ekonomi Produktif (UEP).

\section{METODE PENELITIAN}

Penelitian ini dilaksanakan di Kecamatan Gondang, Kabupaten Mojokerto. Penelitian dilaksanakan selama 1 bulan. Sesuai, dengan tujuan penelitian, metode pada penelitian ini menggunakan pendekatan kualitatif dan strategi etnografi. Penelitian kualitatif etnografi ini menggambarkan kondisi masyarakat atau suatu kelompok sebagai objek pada penelitian (Turmudi, 2019). Studi ini melibatkan peneliti terlibat secara langsung interaksi dengan masyarakat dalam kurun waktu tertentu. Pendekatan kualitatif lebih mengedepankan unsur subyektifitas informan dan sumber primer, bukan sumber dan data sekunder yang telah melalui proses screening seperti audit dan pengolahan lebih lanjut, publikasi, yang 
selanjutnya diolah melalui proses olah data dengan alat (tools) statistic tertentu seperti SPSS, e-views, AMOS, Phyton, dan tools sejenisnya.

Pendekatan penelitian yang digunakan ini, menekankan keterlibatan peneliti dalam kehidupan sehari-hari dalam aktivitas masyarakat setempat. Interaksi sosial serta menelaah persoalan masyarakat setempat dalam sudut panda ekonomi lokal, menjadi basis konsep yang digunakan. Pada penelitian etnografi, bukan hanya peneliti sebagai pelaku yang berupaya mengumpulkan data dan informasi peelitian namun keaktifan dan keterlibatan masyarakat setempat dalam memunculkan kesadaran untuk memanfaatkan asset produktif daerah menjadi pekerjaan ruma tersendiri. Sehingga diperolehlah sebuah temuan yang memang murni (data primer) sesuai dengan kebutuhan penelitian, yang nantinya dapat disampaikan dalam bentuk rekomendasi penelitian ini pula.

Sumber dan jenis data pada penelitian ini didominasi oleh data primer yang diperoleh dari hasil wawancara serta observasi lapangan secara langsung. Sekalipun juga disertai juga dengan dokumentasi dengan pengambilan foto dan video sebagai syarat keabsahan pengambilan data. Selain itu, peneliti mengkaji perilaku UPK dalam mengelola aset produktif PNPM yang digulirkan kepada masyarakat sasaran. Data yang digunakan pada penelitian ini yaitu data primer yang berupa catatan lapangan hasil dari pengamatan dilingkungan tempat penelitian serta wawancara mendalam dengan informan. Informan dalam penelitian yaitu UPK Kecamatan Gondang dan masyarakat yang terlibat dalam program UEP PNPM yang berjumlah 15 orang. Kelima belas orang terbagi menjadi 3 unsur yaitu, Pertama, internal PNPM yang berasal dari unsur pengurus dari struktural Ketua dan Badan Pengurus Harian (BPH); Kedua, masyarakat desa setempat yang merupakan penerima manfaat (end user) dari program pemanfaatan dana bergulir; dan Ketiga adalah tokoh seperti 'sesepuh' dan alim ulama desa setempat yang berperan sebagai pemerhati dan sekaligus pengawas kinerja PNPM.

Selain data primer, dalam penelitian ini juga menggunakan data sekunder yang berupa dokumen dan arsip yang dimiliki UPK Kecamatan Gondang dan Dinas Pemberdayaan Masyarakat dan Desa Kabupaten Mojokerto. Sedangkan tahapan penelitian tersebut dituangkan dalam alur proses penelitian sebagaimana gambar 4 .

Proses penelitian dilakukan melalui beberapa tahapan, diantaranya: 1) melakukan studi awal melalui proses praobservasi yang kemudian dituangkan kedalam susunan monograf, 2) peneliti mengidentifikasi masalah dengan merumuskan masalah apa yang akan diteliti lebih dalam, tanpa adanya rumusan masalah yang tepat maka peneliti akan kehilangan arah dalam menyelesaikan penelitian, 3) kemudian, peneliti menentukan metode apa dan bagaimana pengumpulan data dilakukan untuk menggali kebenaran informasi yang telah diperoleh sebelumnya 4) selanjutnya, peneliti mulai menulis penyusunan laporan hasil penelitian disertai adanya perbaikan atau revisi yang dilakukan hingga menghasilkan artikel yang telah melalui beberapa proses ini.

Menyoal alur dan metode penelitian yang telah disampaikan pada bagian sebelumnya, maka perlu ada validasi data. Validasi data pada penelitian kali ini dengan menggunakan metode triangulasi. Triangulasi adalah upaya validasi yang identik digunakan pada pendekatan kualitatif untuk memperoleh obyektifitas data, yaitu dengan mencari irisan dan kesamaan informasi dari informan yang berlatar belakang berbeda. Adapun metode triangulasi yang digunakan pada penelitian kali ini adalah triangulasi metode dan triangulasi sumber. Triagulasi metode 
dilakukan dengan pencarian data melalui wawancara mendalam dengan informan, observasi dan dokumentasi. Sedangkan triangulasi sumber adalah wawancara mandalam dengan informan yang berlatar belakang berbeda, yang tujuan telah disampaikan pada bagian sebelumnya yaitu diperoleh data dan informasi yang valid, obyektif dan akurat, serta diterima oleh multi-perspektif. Penelitian menggunakan kedua metode triangulasi tersebut.

\section{HASIL DAN PEMBAHASAN}

Melalui Program Pemberdayaan Masyarakat (PNPM) yang berupa pengelolaan aset produktif dalam bentuk dana bergulir dapat dijadikan dasar untuk dimanfaatkan sebagai penggerak perekonomian masyarakat sasaran. Dana bergulir tersebut berupa bantuan modal Usaha Ekonomi Produktif (UEP) yang pengelolaannya dilakukan oleh Unit Pelaksana Kegiatan Kecamatan (UPK). Kegiatan UEP ditujukan bagi rumah tangga miskin dengan harapan dapat meningkatan pendapatannya. Selain menyediakan pe,nambahan modal, adanya program UEP pada PNPM juga bertujuan meningkatan kapasitas pelaku usaha melalui berbagai pelatihan sebagai pendorong agar pelaku usaha dapat memanfaatkan dana bergulir dengan tepat dan berkelanjutan. Perguliran dana melalui UEP dimaksudkan untuk meningkatkan jumlah pelaku usaha dalam sektor informal. Sektor informal dianggap mempu berperan dalam meningkatkan pendapatan masyarakat, mendorong pertumbuhan ekonomi dan mewujudkan stabilitas nasional (Hadi, 2015).

Kecamatan Gondang dipilih sebagai salah satu kecamatan yang berhak menerima bantuan dana bergulir PNPM karena Kecamatan Gondang merupakan salah satu dari 18 kecamatan di Kabupaten Mojokerto yang memiliki potensi sumberdaya yang besar. Namun, tidak diikuti dengan pengelolaan yang memadai. Sehingga pada tahun 1999, melalui Program Pengentasan Kemiskinan, Kecamatan Gondang diberikan kesempatan untuk mengelola aset produktif berupa dana bergulir yang diperuntukkan dalam program SPP dan UEP sejumlah Rp 1.415.712.500. Aset produktif tersebut terus mengalami kenaikan, data terakhir per Bulan Juli 2020 menunjukkan

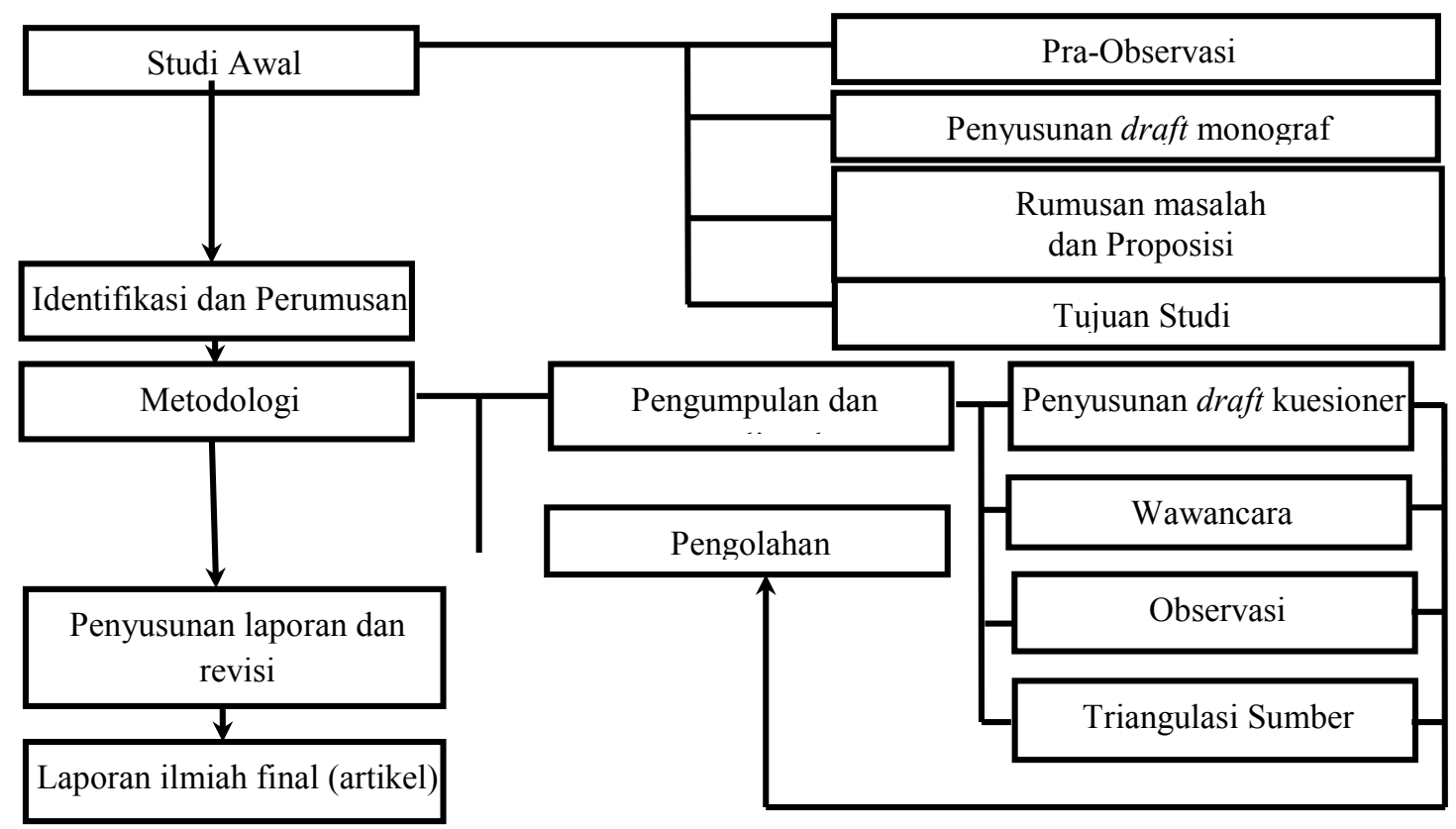

Gambar 4

Bagan Alur Penelitian 
aset produktif Kecamatan Gondang saat ini sebesar Rp 8.912.963.434. Jika dibanding 13 kecamatan lain di Kabupaten Mojokerto, saat ini Kecamatan Gondang menduduki kecamatan dengan aset produktif tertinggi se-Kabupaten Mojokerto.

Menurut buku pedoman PNPM, strategi pengelolaan PNPM dimulai dengan berbagai tahap diantaranya perencanaan, pelaksanaan dan pelestarian kegiatan. Untuk menentukan wilayah sasaran penyaluran aset produktif berupa dana bergulir, terlebih dahulu dilakukan pengamatan kondisi wilayah sasaran untuk mengindentifikasi sumberdaya dan potensi yang dapat mendukung pelaksanaan program. Usaha Ekonomi Produktif (UEP) yang dilaksanakan oleh Unit Pelaksanaan Kegiatan (UPK) Kecamatan Gondang melalui masyarakat Kecamatan Gondang yang tergabung dalam kelompok UEP yang bertujuan menyediakan komponen pendanaan untuk meningkatkan kapasitas rumah tangga miskin. Bantuan dorongan modal melalui UEP menjadi faktor pendukung terhadap keberhasilan kegiatan usaha. Adanya modal dianggap sebagai pondasi sehingga masyarakat mampu meningkatkan hasil produksi, menambah ragam jenis usaha dan memeperluas usahanya (Purwanti, 2013). Berikut kontribusi Unit Pelaksana Kegiatan Kecamatan Gondang dalam mengupayakan keberhasilan pemberdayaan masyarakat dalam program UEP :

a. Memberikan fasilitas berupa dorongan kredit melalui dana bergulir PNPM sesuai kebutuhan masing-masing anggota kelompok UEP yang telah diverifikasi dengan batas maksimal plafon pinjaman Rp 25.000.000. Dorongan kredit pada kelompok usaha sebagai upaya untuk membantu masyarakat sasaran terkait terkendalanya kegiatan usaha karena kurangnya modal usaha yang dimiliki. Menurut (Purwanti, 2013), modal terbukti memiliki pengaruh yang dominan dan signifikan pada perkembangan usaha.

b. Memberikan pelatihan bagi anggota kelompok UEP. Indonesia memiliki peluang dan potensi yang besar terhadap ekonomi digital untuk kemajuan pembangunan (Yalina et al., 2020). Sehingga berbagai bentuk pelatihan termasuk pelatihan mengenai teknologi informasi, pengenalan alat produksi yang baru, pelatihan teknologi produksi, pelatihan manajemen dan sebagainya dalam kegiatan peningkatan kapasitas sumberdaya diupayakan oleh Tim UPK. Saat ini, pelatihan kepada masyarakat sasaran lebih diprioritaskan pada pelatihan kewirausahaan dan inovasi agar masyarakat dapat membuka jenis usaha baru untuk mensukseskan kegiatan kemandirian melalui program pemberdayaan masyarakat

c. Berusaha mengubah cara berfikir masyarakat dan memberikan pemahaman bahwa setiap orang memiliki kelebihan yang dapat dikembangkan. Hal tersebut harus dilakukan secara terus menerus agar tertanam pada diri masyarakat. Pola pikir tersebut akan tertanam didalam kesadaran mereka dan berpotensi menciptakan nilai kewirausahaan dan kemandirian (Zaki et al., 2020). Tujuan dari hal tersebut yaitu untuk memberikan motivasi agar masyarakat tidak hanya bekerja sebagai buruh. Namun, juga berusaha mengembangkan usaha sendiri dengan bantuan kredit dari PNPM.

Upaya yang dilakukan oleh UPK Kecamatan Gondang menunjukkan bahwa UPK mengupayakan potensi yang terdapat di Kecamatan Gondang dengan membuka kesadaran masyarakat bahwa terdapat berbagai potensi yang dapat dimanfaatkan melalui inovasi dan kreasi yang dapat 
menghasilkan pendapatan bagi masyarakat dari kegiatan usahanya masing-masing. Selain itu, ketika masyarakat memiliki keahlian atau ketrampilan tertentu, dapat dijadikan modal dalam mendirikan sebuah usaha meskipun kedudukannya tidak dapat disubordinasikan dengan modal (A. T. R. C. Yudha, 2015) berupa dana bergulir. Dengan begitu harapannya masyarakat dapat mandiri dan tidak berpangku tangan pada pemerintah karena masyarakat juga harus berpartisipasi dalam memberikan dukungan terhadap kontribusi yang diberikan oleh pemerintah melalui berbagai upaya yang telah dilakukan (Hakim et al., 2019)

\section{Upaya Peningkatan Aset Produktif}

Daerah yang maju merupakan daerah yang berkemampuan untuk memenuhi segala kebutuhannya dan tidak hanya bergantung pada bantuan yang disediakan oleh pemerintah, sekalipun pemerintah memberikan bantuan tujuannya sebagai pendorong atau stimulan (Puspayanthi et al., 2017). Sehingga setiap daerah dituntut mampu mengelola secara mandiri segala bentuk bantuan pemerintah agar dapat menghasilkan sesuatu yang berkesinambungan dan berkontribusi untuk menggerakkan pertumbuhan serta kemajuan daerah itu sendiri.

Sebagai partisipan pada proses kemandirian masyarakat, masyarakat untuk mengembangkan potensi, mengontrol sumberdaya dan lingkungannya sendiri, menyelesaikan masalahnya sendiri serta turut berpartisipasi dalam proses pembangunan dan pemerintahan (Pusposari et al., 2015) melalui berbagai program yang disediakan pemerintah sebagai bentuk dukungan. Untuk mengembangkan sebuah usaha, masyarakat membutuhkan penguatan modal (Kurniawan, 2019). Adanya bantuan aset produktif mendorong masyarakat untuk berkembang dan mampu bekerjasma dalam menyukseskan program pemerintah. Hal tersebut dibuktikan dengan adanya peningkatan jumlah kelompok Usaha Ekonomi Produktif (UEP). Pada tahun 1999 diawal program terdapat 40 kelompok yang masing-masing kelompok beranggotakan 10 sampai 30 orang. Jumlah kelompok UEP terus mengalami peningkatan hingga saat ini per tahun 2020 jumlahnya mencapai 99 kelompok yang tersebar di seluruh Kecamatan Gondang. Adapun upaya yang dilakukan oleh UPK Kecamatan Gondang untuk mendukung program UEP agar tetap lestari sekaligus sebagai upaya meningkatkan aset produktif PNPM adalah sebagai berikut :

Pertama, memberikan bunga pinjaman yang relatif rendah. Saat ini, bunga pinjaman UEP yakni sebesar $0,8 \%$ per bulan. Bunga pinjaman yang rendah akan meningkatkan jumlah kredit yang tersalurkan ke masyarakat. Ketika bunga pinjaman rendah atau menurun maka masyarakat akan berspekulasi bahwa keuntungan yang diperoleh dari hasil perputaran dana yang dari usahanya, hasilnya akan jauh lebih besar dari dana yang seharusnya dikembalikan pada PNPM dari dana yang telah dipinjam sebelumnya (Kaunang, 2013). Oleh karena itu, rendahnya bunga pinjaman akan mempengaruhi minat masyarakat untuk melakukan kredit pada PNPM. Rendahnya bunga pinjaman yang ditetapkan sebagai bentuk dedikasi kepada masyarakat karena turut berpartisipasi dalam mengembangkan aset produktif PNPM. Selain itu, sebagai pertimbangan agar masyrakat tidak terjerat hutang rentenir yang bunganya tinggi sehingga semakin membebankan masyarakat.

Kedua, tidak adanya agunan atau jaminan. Ketika seseorang melakukan peminjaman dana di bank dalam bentuk kredit, maka bank akan mempertimbangkan agunan yang dijaminkan oleh nasabah. Adanya agunan menjadi faktor yang penting karena apabila nasabah tidak kooperatif 
dalam melakukan pembayaran kedit, maka agunan berfungsi menggantikan alternatif pembayaran tersebut (Nur \& Utomo, 2013). Sedangkan dalam Program UEP PNPM, masyarakat tidak disyaratkan memberikan jaminan dalam melakukan peminjaman dana. Namun, UPK tetap harus melaksanakan prosedur yang ada untuk tetap melakukan survei.

Ketiga, sistem tanggung renteng. Sistem tanggung rentang merupakan pemerataan tanggungjawab terhadap seluruh anggota kelompok, tanggungjawab dalam konteks ini diartikan sebagai kerjasama antar anggota kelompok atas resiko utang yang dilakukan oleh salah satu atau beberapa orang anggota kelompok. Sistem tanggung renteng mengandung nilai kepercayaan antar anggota kelompok, kerjasama dan saling tolong menolong (Arifin, 2008). Tujuan penggunaan sistem tanggung renteng pada kelompok UEP untuk meminimalisir kemungkinan tdak tertagihnya piutang dana bergulir pada anggota kelompok.

Keempat, akses yang mudah. Saat proses registrasi, verifikasi hingga pencairan dana bergulir UEP, nasabah tidak perlu datang ke kantor PNPM. Seluruh admnistrasi dilakukan melalui satu jalur yaitu ketua kelompok ke UPK. Sehingga masyarakat yang tidak memiliki kendaraan atau terkendala transportasi tetap dapat mengajukan perguliran dana, mengingat sebagian Kecamatan Gondang merupakan wilayah dataran tinggi. Jika dibandingkan dengan lembaga keuangan yang lain, mengharuskan masyarakat datang ke kantor untuk mengajukan pembiayaan. Fasilitas yang diberikan oleh UPK

Kelima, prosedur yang mudah. Prosedur perguliran dana UEP tidak memerlukan banyak persyaratan, nasabah hanya perlu menunjukkan bukti KTP bahwa yang bersangkutan merupakan penduduk asli Kecamatan Gondang. Selain itu, tim verifikasi dan UPK melakukan survei apakah yang bersangkutan layak mendapatkan pinjaman perguliran dana sesuai yang diajukan.

Keenam, kerjasama antar lembaga. Keberadaan berbagai lembaga serta fungsinya sangat diperlukan dalam menjaga keberlanjutan suatu program (Harsanto et al., 2015). Adanya dukungan dari berbagai lembaga diantaranya BKAD, UPK, Tim Verifikasi dan Penanggung Jawab Kelompok yang memiliki peran masingmasing sangat menentukan lestarinya aset produktif. Koordinasi dan kerjasama yang baik antar lembaga dalam menyelesaikan berbagai masalah internal, termasuk permasalahan mengenai adanya tunggakan yang ditanggapi dengan sigap sehingga menjadikan Kecamatan Gondang sebagai kecamatan dengan persentase tunggakan terkecil yaitu $4.35 \%$ dari total keseluruhan aset produktif yang dimiliki.

Dilihat dari berkembangnya aset produktif Kecamatan Gondang dengan persentase kenaikan 530\% dari modal awal yang diberikan oleh PNPM dan diimbangi dengan rendahnya tunggakan yaitu $4.35 \%$ dari total seluruh aset yang dimiliki. Menunjukkan bahwa dana bergulir di Kecamatan Gondang berkembang secara signifikan terhadap peningkatan aset produktif. Menurut data UPK Kecamatan Gondang menunjukkan 99 kelompok UEP $50 \%$ didominasi oleh usaha pertanian, $32 \%$ Toko kelontong dan warung makan, sisanya $18 \%$ pengrajin perabot rumah tangga dan pekerja buruh. Temuan dilapangan menunjukkan bahwa kredit yang dilakukan oleh masyarakat melalui dana bergulir PNPM tidak sepenuhnya digunakan untuk keperluan peningkatan kegiatan usaha melainkan untuk kegiatan konsumsi pribadi. Sehingga, upaya-upaya yang dilakukan oleh UPK untuk mensukseskan pemberdayaan masyarakat tidak sepenuhnya dapat diserap dengan baik oleh masyarakat. Namun, berbanding terbalik dengan perkembangan dana bergulir yang semakin produktif dan 
mengalami peningkatan. Sehingga dalam hal ini, upaya peningkatan kemandirian masyarakat melalui program pemberdayaan masyarakat PNPM cenderung terfokus pada peningkatan aset produktif dan belum sepenuhnya difokuskan pada kegiatan pemberdayaan masyarakat.

\section{SIMPULAN}

Berdasarkan latar belakang, rumusan masalah, tujuan, tinjauan pustaka, metode penelitian, dan pembahasan maka dapat diambil simpulan. Simpulan yang diambil tentunya memiliki relevansi dengan temuan penelitian dan tujuan penelitian. Simpulan penelitiannya adalah sebagai berikut: pertama, tim penyalur dana telah berupaya menyalurkan dana produktif yang memang keperuntukannya untuk peningkatan nilai asset produktif. Namun ternyata dalam proses pemanfaatan, justru tidak sepenuhnya digunakan sebagaimana tujuan awalnya yaitu kegiatan produktif; kedua, program pemberdayaan kemandirian ekonomi masyarakat tidak sepenuhnya digunakan untuk kepentingan produktif, namun justru untuk keperluan konsumtif pribadi dan keluarga. Hal ini tidak dapat sepenuhnya disalahkan, mengingat memang keperluan konsumsi dan kebutuhan sehari-hari masyarakat desa setempat terus berjalan sedangkan pendapatan usaha tidak lancer sebagaimana yang diharapkan. Pada bagian bab simpulan, selain disampaikan kesimpulan penelitian. Berdasarkan hasil dan pembahasan penelitian ini, ada beberapa hal perlu diajukan sebagai saran. Atas dasar hasil dan pembahasan serta simpulan, maka perlu diberikan saran konkret. Saran yang dapat diberikan adalah: 1) memberikan fasilitas berupa dorongan kredit 2) memberikan pelatihan bagi anggota kelompok UEP dan 3) mengubah cara berfikir masyarakat dan memberikan pemahaman kepada masyarakat dengan juga memberikan edukasi dan pendampingan usaha secara berkala. Hal ini dilakukan agar masyarakat merasa 'termanusiakan' dan terawasi sehingga harapannya, diperoleh tujuan awal penelitian ini yaitu kemandirian ekonomi. Sedangkan untuk meningkatkan aset produktif PNPM, upaya yang dilakukan oleh UPK Kecamatan Gondang yaitu Pertama, memberikan bunga pinjaman yang relatif rendah. Kedua, tidak adanya agunan atau jaminan. Ketiga, sistem tanggung renteng. Keempat, akses yang mudah. Kelima, prosedur yang mudah. Keenam, kerjasama antar lembaga. Saran tertuju bagi UPK Kecamatan Gondang, yaitu agar menyeleksi masyarakat yang melakukan kredit pada program UEP untuk memastikan bahwa penggunaannya benarbenar diperuntukkan bagi pengembangan usaha. Pengembangan yang dimaksud adalah sebagai bentuk dukungan terhadap keberhasilan tujuan PNPM dan bukan untuk kegiatan yang bersifat konsumtif, serta melakukan mentoring secara berkala pada kelompok binaan sebagai bentuk evaluasi pemberdayaan agar kelompok binaan dapat terus mengembangkan potensi yang dimiliki.

\section{UCAPAN TERIMA KASIH}

Ucapan terimakasih disampaikan oleh penulis kepada Dosen Pembimbing, Pihak Dinas Pemberdayaan Masyarakat dan Desa Kabupaten Mojokerto. UPK Kecamatan Gondang serta masyarakat yang terlibat dalam penelitian ini sehingga dengan kesempatan yang diberikan oleh seluruh pihak, penulis dapat menyelesaikan tulisan ini. 


\section{DAFTAR PUSTAKA}

Ab Rahman, M. F., Abdullah Thaidi, H. 'Azeemi, Baharuddin, A. S., Ab Rahman, A., \& Ab Rahim, S. F. (2019). Expansion of Agricultural Zakat Revenue in Malaysia on the Basis of the Current Maslahah. Al-Jami'ah: Journal of Islamic Studies, 57(1), 231256. https://doi.org/10.14421/ ajis.2019.571.231-256.

Arifin, S. (2008). Dinamika implementasi konsep sistem tanggung renteng dan kontribusinya pada tercapainya zero bad debt. Jurnal Keuangan Dan Perbankan, 12(3).

BPS. (2019). Potensi Peningkatan Kinerja Usaha Mikro Kecil.

Dewi, L., Hanik, U., Awwaliah, H., \& Yudha, A. T. R. C. (2021). Determinan Harga dan Potensi Sampah sebagai Sumber Modal Ekonomi di Bank Sampah Syariah UINSA Surabaya. Nomicpedia, 1(1), 14-26.

Hadi, D. P. (2015). Strategi Pemberdayaan Masyarakat Pada Usaha Kecil dan Menengah Berbasis Sumber Daya Lokal Dalam Rangka Millenium Development Goals 2015 (Studi Kasus di PNPM-MP Kabupaten Kendal). V(1), 725-736.

Hakim, A. K., Mauludin, M. F., Hermanto, M., \& Rokhim, S. (2019). Model Peningkatan Pendapatan Masyarakat Pedesaan dan Pendampingan Berbasis Kotoran Ternak Sapi Sebagai Lahan Bisnis. Jurnal Litbang Kebijakan, 13.
Harsanto, B. T., Rosyadi, S., \& Simin, S. (2015). Format Kelembagaan Kerja Sama Antar Daerah Untuk Pembangunan Ekonomi Kawasan Berkelanjutan. MIMBAR, Jurnal Sosial Dan Pembangunan, 31(1), 211. https://doi.org/10.29313/ mimbar.v31i1.1317.

Kaunang, G. (2013). Tingkat Suku Bunga Pinjaman dan Kredit Macet Pengaruhnya Terhadap Permintaan Kredit UMKM di Indonesia. Jurnal EMBA, 1(3), 920-930.

Kurniawan, Y. T. (2019). Pengembangan Badan Usaha Milik Desa ( Bumdes ) untuk Menurunkan Jumlah Rumah Tangga Rentan Miskin di Desa Ngroto Kecamatan Pujon Kabupaten Malang Development of Village Owned Enterprises ( Bumdes ) to Reduce the Amount of Poor Household in Village Ngroto. Jurnal Litbang Kebijakan, 13.

Mardiyah,A., \& Ryandono, M.N.H. (2016). Sistem Tanggung Renteng pada Koperasi Assakinal sebagai Bentuk Penerapan Konsep Ta'awun. 2(1), 79-94. https://doi.org/10.20473/ vol7iss20202pp372-388.

Muslim, A. (2017). Analisis Kegagalan Program Nasional Pemberdayaan Masyarakat dalam Membangun Kemandirian Masyarakat Miskin (Studi Kasus di Provinsi Daerah Istimewa Yogyakarta, Jawa Tengah, dan Jawa Timur). Penyuluhan, 13(1), 79-87. 
Novalianis, R. S. G. (2011). Pengaruh Pinjaman Dana Bergulir dan Pendampingan Terhadap Kegiatan Usaha Ekonomi Produktif Pada Program Nasional Pemberdayaan Masyarakat ( PNPM ) Mandiri di Kecamatan Karanggede Kabupaten Boyolali.

Nur, S., \& Utomo, C. (2013). Analisa Nilai Agunan Rumah Tinggal di Medokan Asri Utara XII Surabaya. Jurnal Teknik Pomits, 2(2), 67-71.

Paralaungan, A. N. (2016). Pemberdayaan Sektor Ekonomi Informal: Suatu Tinjauan Empiris. Jurnal Dimensi, $1-7$.

Purwanti, E. (2013). Pengaruh Karakteristik Wirausaha, Modal Usaha, Strategi Pemasaran Terhadap Perkembangan Umkm Di Desa Dayaan Dan Kalilondo Salatiga. Among Makarti.

Puspayanthi, N. L. P. A. D., Wahyuni, M. A., \& Prayudi, M. A. (2017). Penguatan Pengelolaan Keuangan Desa dan Optimalisasi Peran BUMDES untuk Kemandirian Desa pada desa di Kabupaten Jembrana. E-Jurnal S1 Ak Universitas Pendidikan Ganesha, 1(1).

Pusposari, L. F., Shofiyah, S., \& C, C. D. (2015). Pemberdayaan Masyarakat Berorientasi Kemandirian (Studi Pada Masyarakat Pesisir Kecamatan Camplong Kabupaten Sambpang). J-PIPS, 2(1), 42-62.

Reginald, A. R., \& Mawardi, I. (2015). Kewirausahaan Sosial Pada Pondok Pesantren Sidogiri Pasuruan. Jurnal Ekonomi Syariah Teori Dan Terapan, 1(5), 333345. https://doi.org/10.20473/ VOL1ISS20145PP\%P.
Syamsuar, \& Reflianto. (2018). Pendidikan Dan Tantangan Pembelajaran Berbasis Teknologi Informasi Di Era Revolusi Industri 4.0. Pendidikan Dan Tantangan Pembelajaran Berbasis Teknologi Informasi Di Era Revolusi Industri 4.0. https://doi.org/https://doi. org/10.24036/et.v2i2.101343.

Turmudi, M. (2019). Pengaruh Shared Value, Consumer Knowledge Dan Communication Terhadap Minat Nasabah Pada Perbankan Syariah (Studi Pada .... Al-Izzah: Jurnal Hasil-Hasil Penelitian. http:// ejournal.iainkendari.ac.id/alizzah/article/view/1254.

Winarsih, R., Masrifah, A. R., \& Umam, K. (2019). the Integration of Islamic Commercial and Social Economy Through Productive Waqf To Promote Pesantren Welfare. Journal of Islamic Monetary Economics and Finance, 5(2), 321-340. https://doi.org/10.21098/ jimf.v5i2.1065.

Yalina, N., Kartika, A. P., \& Yudha, A. T. R. C. (2020). Impact Analysis of Digital Divide on Food Security and Poverty in Indonesiain 2015-2017. Jurnal Manajemen Teknologi, 19(2), 145-158. https:// doi.org/10.12695/jmt.2020.19.2.3.

Yudha, A., Awwaliah, H., \& Pertiwi, E. M. (2021). SDGs Value and Islamic Philantrophy Through Zakah Institution During the Covid-19. Ihtifaz: Journal of Islamic ..., 4(1), 31-45. https://doi.org/ http://dx.doi.org/10.12928/ijiefb. v4i1.2535. 
Yudha, A. T. R. C. (2015). Jaminan dalam Zaki,I., Widiastuti,T., Tony,A., \& Candra, R. Aqad Pembiayaan $\mathrm{Mu}$ dārabah (2020). Implementation of Islamic Perbankan Syariah di Wilayah Surabaya. Al-Tijarah, 1(1), 37-57.

Yudha, A. T. R. C., \& Muizz, A. (2020). Optimalisasi Potensi Lahan Pertanian untuk Ketahanan Pangan di Kecamatan Panceng, Gresik, Jawa Timur. Journals of Economics Development Issues ( JEDI ), 3(2), 297-308. https://doi. org/https://doi.org/10.33005/jedi. $\mathrm{v} 3 \mathrm{i} 2.55$.

Yudha, A. T. R. C., \& Prayitno, A., Entrepreneurial Culture in Islamic Boarding Schools. International Journal of Innovetion, Creativity and Change, 11(11), 452-469.

Zustika, A. F., \& Yudha, A. T. R. C. (2020). Peer to Peer Lending System in Hifdul Maal Perspective: Evidence From he Fintech Company of Investree. Jurnal Ekonomi Syariah Teori Dan Terapan, 7(8), 15851597. https://doi.org/10.20473/ vol7iss20208pp1584-1597. Rahmaning, D., \& Maulana, A. (2018). (2018). Instrumen Moneter Indonesia: Penentuan Arah Kebijakan. Journals of Economics Development Issues (JEDI ), 1(2), 1-11. https://doi.org/https://doi. org/10.33005/jedi.v1i2.15. 